\title{
PERENCANAAN PEMBELAJARAN PENDIDIKAN PANCASILA DALAM UPAYA MENGUATKAN RASA PERSATUAN DAN KESATUAN INDONESIA PADA MAHASISWA DALAM KONSEP MASYARAKAT YANG MULTIKULTUR
}

\author{
Dwi aprilia sindi wulandari \\ IIK STRADA Indonesia \\ dwiaprilia319@gmail.com
}

\begin{abstract}
Abstrak
Penelitian ini dilakukan karena kegelisahan peneliti mengenai perpecahan yang terjadi karena keragaman Indonesia. Isu-isu perpecahan perbedaan ras, suku, golongan dan agama menjadi hal yang sering terjadi di lingkungan kita. Mahasiswa sebagai agen perubahan mempunyai andil yang penting dalam upaya mencapai tujuan nasional Bangsa Indonesia. Pendidikan Pancasila yang diberikan pada pendidikan tinggi diharapkan mampu menjadi katalis untuk menguatkan rasa persatuan dan kesatuan di kalangan mahasiswa, baik ketika masih menempuh pendidikan maupun setelah mahasiswa menyelesaikan studi dan turun ke masyarakat. Tujuan dari penelitian ini adalah untuk melihat bagaimana perencanaan pembelajaran Pendidikan Pancasila dalam mengupayakan rasa persatuan dan kesatuan mahasiswa dalam konsep masyarakat multikultural. Pendekatan yang digunakan dalam penelitian ini adalah kualitatif dengan metode studi kasus. Tahapan penelitian adalah pengumpulan data, analisis data, dan penafsiran data. Sumber data adalah dosen pengampu mata kuliah Pendidikan Pancasila dan mahasiswa Universitas Buana Perjuangan Karawang.
\end{abstract}

Kata kunci: perencanaan pembelajarn, pendidikan pancasila, multikultur, persatuan dan kesatuan

\section{Latar belakang}

Indonesia merupakan salah satu negara terbesar di dunia dengan keragaman agama dan kepercayaan, suku, budaya dan bahasanya. Selain menjadi keuntungan, hal tersebut juga bisa menjadi tantangan dalam mencapai tujuan nasional bangsa Indonesia dalam hal persatuan dan kesatuan Indonesia. Tantangan dari keanekaragaman tersebut adalah perpecahan karena perbedaan latar belakang, sosial budaya, ras, suku, agama dan kepercayaan. Masalah ini bukan hal yang baru terjadi di Indonesia, beberapa konflik besar mengenai perpecahan karena perbedaan yang sudah terjadi seperti: 1) tragedi sampit;2) tragedi ambon; dan 3) tragedy 1998 (Tempo, 2015). Tentu sebagai Bangsa Indonesia yang menjunjung tinggi nilai-nilai persatuan dan kesatuan, kita tidak ingin kejadian memilukan itu terjadi lagi di Indonesia. 
Mahasiswa yang merupakan agen perubahan tentu mempunyai peranan penting untuk meneruskan nilai-nilai persatuan dan kesatuan bangsa Indonesia baik ketika mereka sedang dan setelah mereka selesai menempuh pendidikan tinggi serta terjun sebagai anggota masyarakat. Persiapan tersebut tentu menjadi tanggungjawab perguruan tinggi dan khususnya Pendidikan Kewarganegaraan. Pendidikan Kewarganegaraan sebagai pendidikan politik dan multikultural diharapkan mampu menjawab tantangan-tantangan keberagaman yang dimiliki oleh Indonesia. Berdasarkan latar belakang masalah tersebut, peneliti tertarik untuk melakukan penelitian dengan judul "Perencanaan Pembelajaran Pendidikan Kewarganegaraan Sebagai Upaya Penguat Rasa Persatuan dan Kesatuan Indonesia Pada Mahasiswa Dalam Konsep Masyarakat Multikultur.

\section{Kasus/masalah}

Mencermati hakikat Pendidikan Kewarganegaraan (PKn), seharusnya ia menjadi pelajaran penting. Bukannya dipandang mata pelajaran sampingan. PKn tidak kalah penting dibanding mata pelajaran lainnya. Tapi mengapa selama ini PKn cenderung kurang diminati siswa? Mengapa PKn kurang mendapat perhatian seperti pelajaran matematika, IPA dan bahasa Indonesia? Apakah karena PKn tidak di-UN-kan di tingkat sekolah dasar (SD)? Pertanyaan itu muncul bila melihat kenyataan bahwa sebagian besar siswa bahkan orangtua sepertinya menganggap remeh pelajaran ini. Sesuatu yang dianggap remeh akan berdampak remeh pula pada hasilnya. Alhasil, pencapaian tujuan PKn pun kurang maksimal. Apakah kita lalu menyalahkan siswa? Tentu tidak. Sudah saatnya kita sebagai pendidik melakukan introspeksi. Apakah selama ini kita sudah mengajar secara baik? Mengapa siswa kurang tertarik belajar PKn? Mengapa belajar PKn katanya membosankan? Dan masih banyak pertanyaan yang dapat memicu kita me-review cara mengajar.

Masalah yang dialami setiap pembelajaran memang amat kompleks. Masalah itu datangnya bisa dari kurikulum, guru, siswa, sarana prasarana, sumber belajar, dan lainnya. Tapi sayangnya banyak pendidik kurang peka terhadap permasalahan yang dihadapi. Berdasarkan pengalaman di lapangan, di sini coba diidentifikasi permasalahan yang pernah dihadapi, yang menyebabkan pembelajaran PKn cenderung kurang menarik, dianggap sepele, membosankan, dan kesan negatif lainnya. Masalah itu antara lain:

Pertama, kurikulum yang terlalu berat. Menurut penulis, konten kurikulum PKn untuk tingkat SD terlalu tinggi dibandingkan kemampuan anak usia SD. Misalnya, untuk materi kelas VI SD semester II. Ambil contoh Standar Kompetensi (SK) 2 Memahami sistem pemerintahan Republik Indonesia, Kompetensi Dasar (KD) 2.1 Menjelaskan proses Pemilu dan Pilkada, 2.2 Mendeskripsikan lembaga-lembaga negara sesuai UUD 1945 hasil amandemen, 2.3 Mendeskripsikan tugas dan fungsi pemerintahan pusat dan daerah. Materi-materi itu selain terlalu tinggi bagi siswa, juga belum mempunyai urgensi dan kegunaan bagi kehidupan siswa. Jikapun materi itu dipelajari siswa, akhirnya sasarannya cuma pada aspek kognitif, tidak menyentuh kehidupan riil siswa.

Kedua, kurangnya kemampuan dalam menangkap kata kunci dalam SK dan KD. Dalam melakukan penelaahan terhadap SK dan KD selama ini, guru masih banyak kekeliruan. Alhasil, apa yang disampaikan menjadi salah sasaran. Kesalahan itu misalnya terjadi pada SK kelas VI semester I. SK 1 Menghargai nilai-nilai juang dalam proses perumusan Pancasila sebagai dasar negara, KD 1.1 Mendeskripsikan nilai-nilai juang dalam proses 
perumusan Pancasila sebagai dasar negara, 1.2 Menceritakan secara singkat nilai kebersamaan dalam proses perumusan Pancasila sebagai dasar negara, 1.3 Meneladani nilai-nilai juang para tokoh yang berperan dalam proses perumusan Pancasila sebagai dasar negara dalam kehidupan sehari-hari.

Karena kesalahan menangkap esensi SK dan KD, pembelajaran cenderung cuma mengarah pada pencapaian aspek kognitif. Seperti contoh SK dan KD di atas, selama ini guru cenderung hanya menekankan pada bagaimana proses perumusan Pancasilanya (kognitif), sehingga saat evaluasi, pertanyaan yang muncul ya sekitar proses perumusan Pancasilanya. Misalnya, siapa tokoh yang merumuskan, tanggal berapa, bagaimana bunyi rumusannya. Kondisi itu menyebabkan kompetensi yang diharapkan dicapai siswa malah terabaikan. Misalnya bagaimana siswa mampu menghargai semangat para pejuang dalam merumuskan Pancasila, bagaimana menghargai perbedaan pendapat dalam suatu musyawarah, dan bagaimana meneladani nilai juang para tokoh yang oleh siswa dapat diaplikasikan dalam belajar. Dan ternyata ini juga terjadi pada tim penyusun soal ujian tingkat kabupaten. Padahal kata kunci dari SK dan KD itu menghargai dan nilai-nilai juang, sehingga semestinya pembelajaran menekankan pada aspek afektif dan perilaku siswa.

Ketiga, mengajar berdasarkan buku teks (textbook centre). Buku teks selama ini menjadi pegangan wajib. Jika kita mengajar cuma mengandalkan buku teks (tanpa menggunakan RPP), arah dan sasaran pembelajaran menjadi tidak fokus.

Keempat, praktek mengajar PKn selama ini lebih banyak berlangsung dengan pendekatan konvensional. Selama mengajar, guru lebih banyak menggunakan metode ceramah dan tanya jawab. Siswa cuma menjadi pendengar di dalam kelas, kemudian menjawab soal. Pembelajaran berlangsung monoton, dan guru menjadi satu-satunya sumber informasi. Selain itu, mengajar PKn jarang menggunakan media yang menunjang. Pembelajaran seperti ini jelas amat membosankan.

Kelima, pembelajaran tidak kontekstual. Materi PKn sebetulnya banyak yang bisa diajarkan sesuai realita kehidupan siswa. Tapi, dalam prakteknya, karena telah terbiasa mengajar dengan ceramah, akhirnya semua materi disajikan dalam bentuk ceramah dan tanya jawab. Alhasil, apa yang diperoleh siswa sekadar apa yang disampaikan gurunya. Itupun jika bisa terserap semua.

Ambil contoh materi kelas I semester II. SK 4 Menerapkan kewajiban anak di rumah dan di sekolah, KD 4.1 Mengikuti tata tertib di rumah dan di sekolah, 4.2 Melaksanakan aturan yang berlaku di masyarakat. Materi ini sebetulnya amat dekat dengan kehidupan siswa. Jika materi ini disajikan dengan ceramah saja, yang terjadi kemudian kompetensi yang terdapat dalam SK itu tidak akan tercapai. Tujuan pembelajaran lagi-lagi cuma mengarah pada pencapaian kemampuan kognitif. Padahal, materi ini menuntut adanya aplikasi, bukan sekadar teori atau hapalan. 
Keenam, evaluasi cenderung mengarah pada aspek kognitif. Sebagai dampak dari kesalahan menangkap esensi SK dan KD serta penggunaan metode ceramah yang menjadi andalan, hasil belajar akhirnya cuma bermuara pada pengetahuan. Padahal, hasil belajar semestinya meliputi semua domain: kognitif, afektif dan psikomotor

\section{Tinjauan pustaka}

Pendidikan multikultural adalah merupakan suatu gerakan pembaharuan dan proses untuk menciptakan lingkungan pendidikan yang setara untuk seluruh siswa. Sebagai sebuah gerakan pembaharuan, istilah pendidikan multicultural masih dipandang asing bagi masyarakat umum, bahkan penafsiran terhadap definisi maupun pengertian pendidikan multicultural juga masih diperdebatkan di kalangan pakar pendidikan.

Seperti pendapat Andersen dan Cusher (1994) sebagaimana dikutip Mahfud ( 2008 ), bahwa pendidikan multicultural diartikan sebagai pendidikan mengenai keragaman kebudayaan. Sedangkan Hernandez ( 1989 ), mengartikan pendidikan multikultural sebagai perspektif yang mengakui realitas sosial, politik, dan ekonomi yang dialami oleh masing-masing individu dalam pertemuan manusia yang kompleks dan beragam secara kultur, dan merefleksikan pentingnya budaya, ras,seksualitas dan gender,etnisitas, agama, status social, ekonomi, dan pengecualian-pengecualian dalam proses pendidikan.Pendidikan multikultural merupakan suatu proses transformasi yang tentunya membutuhkan waktu panjang untuk mencapai maksud dan tujuannya. Menurut Zamroni (2011) disebutkan beberapa tujuan yang akan dikembangkan pada diri siswa dalam proses pendidikan multikultural, yaitu :

a. Siswa memiliki kemampuan berpikir kritis atas apa yang telah dipelajari.

b. Siswa memiliki kesadaran atas sifat sakwasangka atas fihak lain yang dimiliki,dan mengkaji mengapa dan dari mana sifat itu muncul, serta terus mengkaji bagaimana cara menghilangkannya

c. Siswa memahami bahwa setiap ilmu pengetahuan bagaikan sebuah pisau bermata dua dapat dipergunakan untuk menindas atau meningkatkan keadilan sosial.

d. Para siswa memahami bagaimana mengaplikasikan ilmu pengetahuan yang dimiliki dalam kehidupan.

e. Siswa merasa terdorong untuk terus belajar guna mengembangkan ilmu pengetahuan yang dikuasainya.

f. Siswa memiliki cita-cita posisi apa yang akan dicapai sejalan dengan apa yang dipelajari.

g. Siswa dapat memahami keterkaitan apa yang dilakukan dengan berbagai permasalahan dalam kehidupan masyarakat-berbangsa.

\section{Pembahasan}

Pembahasan hasil triangulasi ialah menyusun perencanaan pembelajaran dalam pembelajaran Pendidikan Pancasila untuk menguatkan rasa persatuan dan kesatuan Indonesia dalam masyarakat multikultur tidaklah rumit, karena ketika dosen melakukan perencanaan pembelajaran sudah sesuai dengan langkah-langkah yang semestinya. Karena untuk memulai sebuah proses belajar mengajar tentunya dosen sebelumnya harus 
merencanakan pembelajaran terlebih dahulu agar pembelajaran yang akan diterapkan di dalam kelas terarah, memiliki tujuan pembelajaran, dan hasil pembelajaran. Itu semua sudah dituangkan dalam RPS terkait pembelajaran yang akan diterapkan kepada mahasiswa dalam proses belaajar mengajar.

Tentunya dosen harus cukup matang dalam mempersiapkan pembelajaran, sebelum memulai pembelajaran terlebih dahulu dosen memberitahu mahasiswa terkait akan diterapkannya terkait capaian pembelajaran yang akan dicapai dalam proses pembelajaran yang akan dipelajari. Perencaan pembelajaran tentunya harus sistematis maka dari itu dosen menbuat rencana pembelajaran semester (RPS) untuk menjadi acuan ketika dosen mengajar agar tidak melenceng dari apa yang sudah direncanakan untuk pelaksanaan pembelajaran. Dalam kegiatan belajar mengajar perlunya seorang pengajar membuat RPS terlebih dahulu karena dengan RPS tersebut pengajar menjadi mudah untuk mengajar dan terdapat pula tahapan-tahan yang harus di lakukan oleh pengajar

\section{Kesimpulan}

Berdasarkan hasil penelitian dapat disimpulkan bahwa menguatkan rasa persatuan dan kesatuan Indonesia dalam konsep masyarakat multikultur dapat dilakukan melalui pembelajaran Pendidikan Pancasila pada perguruan tinggi. Perencanaan pembelajaran dilakukan sesuai dengan tahapan-tahapan yang ada yakni dengan memperhatikan materi, model, media, dan karakteristik mahasiswa sehingga memudahkan dalam proses pembelajran untuk mencapai tujuan pembelajaran. Hasil belajar yang tampak pada pembelajaran Pendidikan Pancasila untuk menguatkan nilai persatuan dan kesatuan Indonesia yaitu perubahan dalam pemahaman tentang nilai keberagaman, bahwa masyarakat Indonesia itu teridiri dari bermacam-macam suku, budaya, adat,agama dan latar belakang. Sehingga membuat mahasiswa dapat bertindak dan berperilaku sesuai dengan nilai-nilai Pancasila, toleransi, menjunjung nilai kesatuan dan persatuan dalam bingkai keberagaman. Sedangkan hambatan yang dihadapi adalah pemahaman warganegara tentang nilai-nilai keberagaman bangsa Indonesia, egoisme kesukuan dan agama, sehingga toleransi antar perbedaan sulit untuk

\section{Daftar pustaka}

Repelita, T., Sofyan, F. S., \& Susanto, E. (2021). PERENCANAAN PEMBELAJARAN PENDIDIKAN PANCASILA DALAM UPAYA MENGUATKAN RASA PERSATUAN DAN KESATUAN INDONESIA PADA MAHASISWA DALAM KONSEP MASYARAKAT YANG MULTIKULTUR. PROSIDING KONFERENSI NASIONAL PENELITIAN DAN PENGABDIAN UNIVERSITAS BUANA PERJUANGAN KARAWANG, 1(1), 581-587.

Sodik, M. A., \& Nzilibili, S. M. M. (2017). The Role Of Health Promotion And Family Support With Attitude Of Couples Childbearing Age In Following Family Planning Program In Health. Journal of Global Research in Public Health, 2(2), 82-89. 
Oktoriani, E. N., Sutrisno, J., Mayasari, E., \& Sodik, M. A. (2018). Analysis of medical record complete flexibility to complete claims of health BPJS RS Baptis Kota Batu. Journal of Global Research in Public Health, 3(1), 46-53.

Sodik, M. A. (2018, September). Analysis of Improved Attitude of Youth in HIV/AIDS Prevention through the Provision of Health Education with Peer Education. In The 2nd Joint International Conferences (Vol. 2, No. 2, pp. 495-502).

Sodik, M. A., \& Setyani, A. T. (2018). Effect of Smoking For Teens Against Behavior and Social Interaction.

Sodik, M. A., Suprapto, S. I., \& Pangesti, D. (2013). Faktor-Faktor Yang Berhubungan Dengan Pelaksanaan Pelayanan Prima Pegawai Di Rsui Orpeha Tulungagung. STRADA Jurnal Ilmiah Kesehatan, 2(1), 24-32.

Setyani, A. T., \& Sodik, M. A. (2018). Pengaruh Merokok Bagi Remaja Terhadap Perilaku dan Pergaulan Sehari-hari.

Attoriq, S., \& Sodik, M. A. (2018). Pencegahan Dan Pengendalian Infeksi Terkait Pelayanan Kesehatan Di Lahan Praktik.

Siyoto, S., \& Sodik, M. A. (2015). Dasar metodologi penelitian. Literasi Media Publishing.

Sodik, M. A. (2018). Merokok \& Bahayanya. 